Advance Journal of Food Science and Technology 14(1): 29-32, 2018

DOI:10.19026/ajfst.14.5423

ISSN: 2042-4868; e-ISSN: 2042-4876

(C) 2018 Maxwell Scientific Publication Corp.

Submitted: July 14, $2014 \quad$ Accepted: October 12, 2014

Published: January 25, 2018

\title{
Research Article \\ Fortification of Al-Jameed Bouillon by Adding Barley and Wheat Bran and Study its Effect on Chemical and Sensory Properties
}

\author{
Malak M. Angor \\ Al-Huson University College, Al-Balqa Applied University, Al-Huson, Jordan, Tel.: 00962797633048
}

\begin{abstract}
The aim of this study is to investigate the influence of wheat bran and barley fortification at different levels $(3,5$ and $7 \%)$ on the percentage of fiber in Jameed that can reduce intestinal cholesterol absorption and other nutrients and study its effect onash, protein content and sensory attribute of this product. The results have shown that all levels of wheat bran and barley increase fiber, ash and protein percentage in Al-jameed Bouillon. The highest percentage of fiber, ash and protein were at level $7 \%$ wheat bran and for $7 \%$ barley evidence to the result, comparing with control sample. The sensory attributes were almost improved as a result of using the fiber (barley and wheat bran) at different levels.
\end{abstract}

Keywords: Barley, bouillon, fiber, fortification, jameed, wheat bran

\section{INTRODUCTION}

The delicious and largely popular Jordanian national dish is Mansaf. It is a popular meal in various parts of Jordan and some Arab countries. Mansaf has a very high nutritional value. It is consists of cooked pieces of lamb meat spread over a bed of rice and thin bread and sprinkled with nuts. The most prominent ingredient in mansaf is Jameed. Jameed stones are made from yoghurt which is churned for nearly $1 \mathrm{~h}$ to remove the butter, then take shaneneh (yoghurt without fat) after that it should be drained it until it become a soft and smooth shaneneh sauce and then the last procedure will be draying it to get the form of jameed (Al-Qudah and Tawalbeh, 2011).

Jameed bouillon is made by soaking jameed stones with water and then mixing. It is preferable to keep it packed in an in sterilized aluminum bags to keep stabilized at the same temperature of room or the surrounding environment. This solution is easier to prepare mansaf. The Composition of Jameed is a liquid fermented dairy product usually made from goats, sheep's and cow's milk (Al-Qudah and Tawalbeh, 2011), which containper $250 \mathrm{~g}$; total fat $7.5 \mathrm{~g}$, total carbohydrate $4 \mathrm{~g}$, protein $5.7 \mathrm{~g}$, sodium $159 \mathrm{mg}$, calcium $0.75 \mathrm{mg}$.

Mansaf contain high amount of fat, which source from meat and from ghee or oil which is added to mansaf. High consumption of fat has been related to obesity and other diseases like coronary heart diseases, high cholesterol levels, etc. (Angor et al., 2013), On the other hand consumer awareness of the health implications of eating foods with a high fat content is on the increase (Angor, 2016).

Bran is one of the richest sources of dietary fiber and high protein content $13 \%$. It is the outer husk of wheat, rice and other cereal grains (Stevenson et al., 2012). At one time most bran was thrown out wheat grains were milled (Ade et al., 2014).

In the1960's scientists had published several reports which stated that bran other types of fiber could prevent heart attacks, intestinal disorders and cancer of the breast, colon, prostate and uterus (Ade et al., 2014). If Wheat bran used properly in a high-fiber diet can help preventing intestinal disorders. Hence, it helps to prevent constipation. Bran may also benefits people suffering from hemorrhoids (Ade et al., 2014).

Barley is a rich source of soluble fiber and protein content (11.6\%) (Dhingra et al., 2012) (.B-glycan, is fraction of the soluble dietary fiber, it is the primary component in barley which is responsible for lowering serum cholesterol and blood glucose (Hou and Jimenez, 2012). The Food and Drug Administration (FDA) finalized a rule in 2006 allowing barley foods to carry a health claim specific to soluble fiber and coronary heart disease (Hou and Jimenez, 2012). It Barley can be part of the solution to the development of healthy foods in American diet (Hou and Jimenez, 2012).

Fiber can reduce the lipid retention, improve textural properties and structure and reduce caloric content by acting as a bulking agent (Jalal et al., 2016).

Consumption of products containing high fiber may prevent or decrease hypertension, hypercholesterolemia, obesity, gastrointestinal 
disorders, coronary heart disease and cancer (Jalal et al., 2016). The aims of this study are using fiber (barley and wheat bran) in jameed bouillon to reduce intestinal lipid absorption and study Ash, protein, fiber content and sensory attribute of this product.

\section{MATERIALS AND METHODS}

Preparation of Jameed sample: Jameed bouillon (Almallah) is obtained from a local market and the fiber was prepared by grind barley and wheat bran using a grinder (LASKA 130, Austria) and they were sieved inmish $(330 \mu)$.

Then adding the grinding fiber to jameed solution and mixed after and prepare mixture in specific concentration from barley $(3 \%, 5 \%$ and $7 \%)$ and wheat bran $(3 \%, 5 \%$ and $7 \%)$.

\section{SAMPLE ANALYSES}

Chemical methods: Samples were analyzed for moisture, protein, ash and fiber content according to AOAC (Association Official Analytical Chemists) (2000), each analysis was carried out in duplicate.

Moisture Content (MC) was determined by an oven-drying method in which minced samples were placed in dishes and held in an oven (oven, air circulation and typelmodel $\mathrm{A} / 45$ ) at $102^{\circ} \mathrm{C}$ until the weight stable.

Ash Content (AC) was determined by amufflefurnace (automatic muffle furnace, cat.no.OSK405) method in which samples were placed in Crucible and held in an oven muffin-furnace at $500^{\circ} \mathrm{C}$ for $2 \mathrm{~h}$.

Protein Content (PC) was determined by the Kjeldahl method, sample digested with a strong acid (sulphuric acid) so that it releases nitrogen which can be determined by a suitable titration technique. The amount of protein present is then calculated from the nitrogen concentration of the food.

Fiber content (weende method) was determined by crud fiber method, which involved treating the food after extraction of fat from the sample high in this fraction with boiling dilute sulphuric acid (1.25\%) under reflux condenser for $30 \mathrm{~min}$, washing the residue, boiling the residue with dilute sodium hydroxide $(1.25 \%)$ as an sulphuric acid, washing and treating with alcohol and finally ether. The final residue, the crude fiber, is then filtered, dried, weighed $\left(\mathrm{W}_{1}\right)$, then burned (ashing), weighted $\left(\mathrm{W}_{2}\right)$.

Sensory evaluation: Samples from each treatment were evaluated by a40-member panel, chosen from the employees and students of the Department of Nutrition and Food Technology, Al-Balqa University. The panelists were of both sexes and different ages. Before evaluating the samples, they were familiarized with the test procedure and use of the rating system. Each sample was evaluated for appearance, color, flavor, taste and overall acceptability, using a five-point hedonic scale on which 5 was "like extremely" and 1 was "dislike extremely". Small amounts of bread and water were used between samples to neutralize any lingering taste from the previous sample. All treatments were evaluated in duplicate on separate occasions.

Statistical analysis: Statistical analysis of data was carried out using Statistical Analysis System package (SPSS, 1988). The data obtained were analyzed using a completely Randomized Design to study the effect of treatment $\mathrm{s}$ on the protein $\%$, Fiber $\%$, Ash $\%$ and moisture \%, specific volume and sensory scores. The significant Difference (LSD) method.

\section{RESULTS AND DISCUSSION}

Table 1 shows the protein $\%$, Fiber $\%$, Ash $\%$ and moisture content of Jameed solution mixed with different percentage of wheat bran. The data shows that all levels of wheat bran used were effective in increase the fiber, ash and protein percent when compared to those of the (control) sample. These results were agreed with Tomic et al. (2017) who concluded that fortification of fermented dairy products with insoluble dietary fiber is an interesting way to increase consumers' fiber intake and increase Ash content.

However, wheat bran from $7 \%$ of Jameed sample had significantly $(\mathrm{p} \leq 0.05)$ the highest fiber and protein content $(1.85 \%, 5.93)$ respectively and the wheat bran for sample $(3 \%)$ had significantly $(\mathrm{p} \leq 0.05)$ the lowest fiber and protein content $(1.15 \%, 3.72 \%)$ respectively when compared with other samples. The highest percentage of ash was found in the sample (7\%) of wheat bran and was reported $6.48 \%$.

Table 2 shows the protein, Fiber, Ash and moisture content of jameed solution mixed with different levels of barley $(3,5,7 \%)$. The data shows that all levels of barley that had been used were effective in increasing the fiber and protein content when compared to the control sample. These results were agreed with AlMarazeeq and Angor (2017) whom concluded that the addition of wheat germ in biscuit making at level of $20 \%(\mathrm{w} / \mathrm{w})$ enhanced the nutritional value by increasing protein and total mineral content. Also these results agreed with Al-Marazeeq et al. (2017) who concluded that The protein, ash and fat contents were significantly high $(p<0.05)$ in Pomegranate Molasses fortified with Wheat Germ.

However, barley for $7 \%$ of Jameed sample had significantly $(\mathrm{p} \leq 0.05)$ the highest fiber and protein $(2.25 \%, 5.34 \%)$ respectively. The highest percentage of ash was found in the sample $7 \%$ of barley, it was reported $5.10 \%$,

Sensorial characteristics of the Jameed fortification are attractive to the consumers. Mean hedonic scores for appearance, color, flavor, taste and overall 
Adv. J. Food Sci. Technol., 14(1): 29-32, 2018

Table 1: Protein, fiber, Ash and moisture content for Al-jameed mixed at different levels of wheat bran

\begin{tabular}{lllll}
\hline Treatment wheat bran $\%$ & Protein $\%$ & Fiber $\%$ & Ash $\%$ & Moisture $\%$ \\
\hline $3 \%$ & $3.72^{\mathrm{c}}$ & $1.15^{\mathrm{c}}$ & $4.35^{\mathrm{b}}$ & $89.70^{\mathrm{a}}$ \\
$5 \%$ & $4.86^{\mathrm{b}}$ & $1.45^{\mathrm{b}}$ & $4.87^{\mathrm{b}}$ & $89.65^{\mathrm{a}}$ \\
$7 \%$ & $5.93^{\mathrm{a}}$ & $1.85^{\mathrm{a}}$ & $6.48^{\mathrm{a}}$ & $82.84^{\mathrm{c}}$ \\
Control & $2.29^{\mathrm{d}}$ & $0.22^{\mathrm{d}}$ & $2.63^{\mathrm{c}}$ & $87.60^{\mathrm{b}}$ \\
$\mathrm{P}^{2}$ & $* *$ & $* *$ & $* *$ & $* *$
\end{tabular}

values are the means of four replicates, means with different matching letters within the same column are significantly $(* * ; \mathrm{p} \leq 0.05)$ different according to LSD

Table 2: Protein, Ash, moisture and fiber content for Al-jameed mixed with different levels of barley

\begin{tabular}{lllll}
\hline Treatment barley $\%$ & Protein $\%$ & Fiber $\%$ & Ash $\%$ & Moisture $\%$ \\
\hline $3 \%$ & $3.43^{\mathrm{c}}$ & $1.13^{\mathrm{b}}$ & $4.75^{\mathrm{a}}$ & $78.55^{\mathrm{c}}$ \\
$5 \%$ & $4.56^{\mathrm{b}}$ & $1.95^{\mathrm{a}}$ & $4.86^{\mathrm{a}}$ & $87.14^{\mathrm{a}}$ \\
$7 \%$ & $5.34^{\mathrm{a}}$ & $2.25^{\mathrm{a}}$ & $5.10^{\mathrm{a}}$ & $84.63^{\mathrm{b}}$ \\
Control & $2.29^{\mathrm{d}}$ & $0.22^{\mathrm{c}}$ & $2.63^{\mathrm{b}}$ & $87.60^{\mathrm{a}}$ \\
\hline
\end{tabular}

Values are the means of tri replicates, means with different matching letters within the same column are significantly $(* * ; p \leq 0.05)$ different according to LSD

Table 3: Appearance, color, flavor, taste and overall acceptability scores for Al-Jameed mixed with different levels of barley

\begin{tabular}{llllll}
\hline Treatments & Appearance & Color & Flavor & Taste & Overall acceptability \\
\hline $7 \%$ barley & 3.77 & 4.31 & 3.68 & $3.54^{\mathrm{b}}$ & $3.75^{\mathrm{a}}$ \\
$5 \%$ barley & 3.59 & 3.95 & 3.50 & $3.54^{\mathrm{b}}$ & $3.50^{\mathrm{b}}$ \\
$3 \%$ barley & 3.72 & 4.18 & 3.72 & $3.72^{\mathrm{b}}$ & $3.89^{\mathrm{a}}$ \\
Control & 3.68 & 4.27 & 4.00 & $4.09^{\mathrm{a}}$ & $3.97^{\mathrm{a}}$ \\
$\mathrm{P}^{2}$ & ns & ns & ns & $* *$ & $* *$ \\
\hline
\end{tabular}

Each means is the average of 40 reading, where 5 refers to like extremely, either like or dislike and 1 refers to dislike extremely. Values within the same column followed by different letter are significantly $(* * ; p \leq 0.05)$ different according to LSD

Table 4: Appearance, color, flavor, taste and overall acceptability scores for Al-Jameed mixed with different levels of wheat bran

\begin{tabular}{llllll}
\hline Treatments & Appearance & Color & Flavor & Taste & Overall acceptability \\
\hline $7 \%$ wheat bran & 3.45 & 3.81 & $3.31^{\mathrm{c}}$ & $3.45^{\mathrm{c}}$ & $3.50^{\mathrm{c}}$ \\
$5 \%$ wheat bran & 3.72 & 4.18 & $3.68^{\mathrm{b}}$ & $3.68^{\mathrm{b}}$ & $3.79^{\mathrm{b}}$ \\
$3 \%$ wheat bran & 3.72 & 3.77 & $3.72^{\mathrm{a}}$ & $3.50^{\mathrm{c}}$ & $3.56^{\mathrm{b}}$ \\
Control & 3.68 & 4.27 & $4.00^{\mathrm{a}}$ & $4.09^{\mathrm{a}}$ & $3.97^{\mathrm{a}}$ \\
$\mathrm{P}^{2}$ & ns & ns & $* *$ & $* *$ & $* *$ \\
\hline
\end{tabular}

Each means is the average of 40 reading, where 5 refers to like extremely, either like or dislike and 1 refers to dislike extremely. Values within the same column followed by different letter are significantly $(* * ; p \leq 0.05)$ different according to LSD

acceptability of the jameed fortification mixed with different levels of wheat bran and barley $(3 \%, 5 \%, 7 \%$, control) attribute are presented in Table 3 and 4.

The result in Table 3 shows all treatments level shad no significant difference $(\mathrm{p} \leq 0.05)$ between them in appearances, color, flavor and overall acceptability values. These results were agreed with Jalal et al. (2016) he reported that modified milk (where fat had been replaced by oils enriched in w-3 polyunsaturated fatty acids) had no effect on yoghurt flavor. All treatments had significantly $(\mathrm{p} \leq 0.05)$ lower taste score compared to control, but numerically very little, these results were agreed with Tomic et al. (2017) who reported that the fortified yoghurt with fiber were classified into the 'very good' quality category, despite the lower quality scores texture and some bitterness.

Table 4 shows the scores for appearances, color, flavor, taste and overall acceptability for Al-jameed mixed with different levels of wheat bran. The results show that the appearances and color values had no significant difference $(\mathrm{p} \leq 0.05)$ between all treatments compared to control. While flavor, taste and overall acceptability were having significant difference $(p \leq 0.05)$ between treatments compared to control, but numerically the differences between treatments were very little.

\section{CONCLUSION}

The results have shown that all levels of wheat bran and barley increase the fiber, ash and protein percentage in Al-jameed Bouillon. The most effective level for increasing fiber, ash and protein percentage was $7 \%$ for both wheat bran and for barley. The sensory attributes were improved as a result of using the fiber (barley and wheat bran) at different levels.

\section{REFERENCES}

Ade, K.D., E.A. Lal and A.S. Rathod, 2014. Development and quality evaluation of pineapple pomace and wheat bran fortified biscuits. Int. J. Res. Eng. Adv. Technol., 2(3): 1-6.

Al-Marazeeq, K.M. and M.M. Angor, 2017. Chemical characteristic and sensory evaluation of biscuit enriched with wheat germ and the effect of storage time on the sensory properties for this product. Food Nutr. Sci., 8(2): 189-195. 
Al-Marazeeq, K., M. Abdulluh and M. Angor, 2017. Characterization and sensory evaluation of pomegranate molasses fortified with wheat germ. Adv. J. Food Sci. Technol., 13(4): 178-181.

Al-Qudah, Y.H.F. and Y.H. Tawalbeh, 2011. Influence of production Area and type of milk on chemical composition of Jameed in Jordan. J. Rad. Res. Appl. Sci., 4: 1263-1270.

Angor, M.M., 2016. Reducing fat content of fried potato pellet chips using carboxymethyl cellulose and soy protein isolate solutions as coating films. J. Agric. Sci., 8(3): 162-168.

Angor, M.M., R. Ajo, W. Al-Rousan and B. AlAbdullah, 2013. Effect of starchy coating films on the reduction of fat uptake in deep-fat fried potato pellet chips. Ital. J. Food Sci., 25(1): 45-50.

AOAC, 2000. Official Method of Analysis. 17th Edn., Association of Official Analytical Chemists, Washington, DC.

Dhingra, D., M. Michael, H. Rajput and R.T. Patil, 2012. Dietary fibre in foods: A review. J. Food Sci. Technol., 49(3): 255-266.
Hou, G. and V. Jimenez, 2012. Development of barleyfortified instant noodles. AACC Int., 1: 53-54.

Jalal, H., P.A. Para, S. Ganguly, S. Devi, M.M. Bhat, S.A. Bukhari and K. Qadri, 2016. Fortification of dairy products: A review. World J. Biol. Med. Sci., 3(1): 23-35.

SPSS, 1988. Statistical Package for the Social Sciences. Version 15.0, IBM (International Business Machines Corporation) Crop, New York.

Stevenson, L., F. Phillips, K. O'Sullivan and J. Walton, 2012. Wheat bran: Its composition and benefits to health, a European perspective. Int. J. Food Sci. Nutr., 63(8): 1001-1013.

Tomic, N., B. Dojnov, J. Miocinovic, I. Tomasevic, N. Smigic, I. Djekic and Z. Vujcic, 2017. Enrichment of yoghurt with insoluble dietary fiber from triticale - A sensory perspective. LWT, 80: 59-66. 